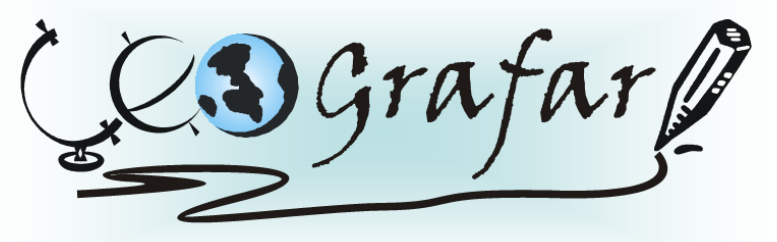

Revista Eletrônica do Programa de Pós-Graduação em Geografia - UFPR

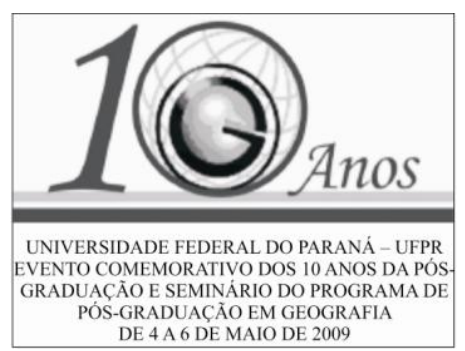

\title{
TURISMO, DESENVOLVIMENTO E POLÍTICAS PÚBLICAS: UM FOCO EM SÃO JOSÉ DOS PINHAIS NO CONTEXTO DA REGIÃO METROPOLITANA DE CURITIBA
}

\author{
RUBENS RONDON KASSAR ${ }^{1}$ \\ MARCOS AURÉLIO T. SILVEIRA ${ }^{2}$ \\ PRODUÇÃO E TRANSFORMAÇÃO DO ESPAÇO URBANO-REGIONAL
}

O presente projeto de pesquisa tem a finalidade de abordar o setor de turismo na Região Metropolitana de Curitiba (RMC), especificamente o município de São José dos Pinhais, seu processo de desenvolvimento recente visto a implementação de políticas públicas nos últimos anos no contexto da região. O município está localizado $14,5 \mathrm{Km}$ de Curitiba e tem privilegiada posição geográfica, pois se encontra na mediatriz dos grandes centros urbanos da América Latina. Sua população é de aproximadamente 261 mil habitantes, base econômica fundamentada no setor secundário e infraestrutura nas áreas de saúde, educação, comunicação, transportes, energia, serviços e saneamento básico. Na atualidade o município é considerado polo de desenvolvimento no estado, justificado principalmente pela implantação de indústrias automobilísticas na região tendo sido resultado de políticas públicas operacionalizadas pelo poder público estadual em parceria à órgãos municipais. No bojo desse ciclo desenvolvimentista é possível afirmar que um setor, reconhecidamente importante da economia mundial atual - o turismo - tem participado de forma incisiva nas Políticas de Desenvolvimento nos municípios brasileiros e esse é o caso de São José dos Pinhais. A atividade do turismo detém hoje grande parte do Produto Interno Bruto (PIB) de muitos países e deixou de ser apenas sinônimo de lazer para assumir seu papel de agente social, político, econômico e ambiental. Dessa forma busca-se desenvolver novas perspectivas de políticas públicas por intermédio de análise e levantamento de dados realizados na localidade com o intuito de tecer e propor considerações para o desenvolvimento do turismo em São José dos

\footnotetext{
${ }^{1}$ rrkassar@hotmail.com

${ }^{2}$ Professor orientador
} 
Pinhais de forma permanente e sustentável com a implementação do setor e ratificação da mesma como atividade importante para o município, sua comunidade e entorno. Justifica-se o presente estudo buscar na ciência geográfica o melhor campo para poder desenvolvê-la visto o objeto de estudo estar correlato à produção e transformação do espaço urbano-regional. Assim posto, o objetivo deste trabalho é analisar o impacto dessas transformações sócio-econômicas para o turismo em São José dos Pinhais.

Palavras-chave: Políticas Públicas; Desenvolvimento; Turismo 